\title{
On Ideological and Political Transformation of College English Teaching
}

\author{
Si-Yang LIU* \\ Foreign Language Department \\ JLICT \\ Jilin City, China
}

\begin{abstract}
In order to implement the idea of ideological and political theories teaching in all courses and make College English classroom an ideological front of moral education, it is necessary to carry out ideological and political transformation of College English teaching in view of the current situation of the lack of Chinese ideological and cultural content and political elements, rigid and outdated education methods. The ways of ideological and political reform of College English teaching are suggested as follows: to tap education resources in teaching materials, to combine the first classroom teaching and the second classroom activities, to integrate moral education into the whole teaching system, and to improve teachers' ability of carrying out ideological and political theories teaching. With such efforts, a new pattern of College English course will be constructed and the connotation of teaching will be reshaped.
\end{abstract}

Keywords-College English; transformation; moral education; ideological and political theories teaching in all courses

\section{INTRODUCTION}

On October 18, 2017, at the 19th National Congress of the Communist Party of China (CPC), General Secretary Xi Jinping solemnly declared: "With decades of hard work, socialism with Chinese characteristics has crossed the threshold into a new era. This is a new historic juncture in China's development. [1]" In the new era, with the comprehensive national strength constantly improving, China has a greater say in the world, which has brought rapidly increasing attentions from the international community and the public to China. In order to better present China's image and make China's voice heard worldwide, college students, as talents serving the country and society, should undertake the task of spreading and infiltrating our unique cultural characteristics with English as a tool. English, as a language is the medium of international exchange of ideas and culture, and as a discipline in China is a humanistic quality education course with a wide audience. In English learning, in fact, intense cultural and ideological collision between China and the West can be found any time and any place. Now it is time to explore in College English teaching about how to make students understand Western culture while being familiar with China's national conditions, how to strengthen socialist ideals and beliefs, strengthen cultural self-confidence, and ultimately realize the whole process and all-round education of foreign language course. $\mathrm{Xi}$ pointed out that "we should take moral education as the central link and integrate the ideological and political work throughout the whole process of education and teaching, and make all kinds of courses and ideological and political theory courses go hand in hand to form a synergistic effect. [2]" Therefore, College English teaching must be integrated into ideological and political education and undertake the task of "ideological and political theories teaching”.

\section{THE PROPOSITION OF THE CONCEPT OF "IDEOLOGICAL AND POLITICAL THEORIES TEACHING IN All COURSES"}

Since 2004, with the publication of a series of important documents, such as "Opinions on Further Strengthening and Improving Ideological and Political Education of College Students", Chinese local governments have begun to explore the transformation of ideological and political education through giving full play to the leading role of classroom teaching, and Shanghai is the pioneer of curriculum reform. Taking "moral education" as the core idea of reform, since 2010 teachers and others in the education field of Shanghai have undertaken the pilot project of national education system reform "Overall Planning of Moral Education Courses in Primary School, Secondary School and College". Based on the research, it has formed a top-level content system framework guided by socialist core values and with political identity, national consciousness, cultural self-confidence and civil personality being key points. In 2014, the researchers further included the content of moral education in some important projects of comprehensive education reform, to explore the transformation from "teaching in ideological and political courses" to "ideological and political theories teaching in other courses", emphasizing to pay full attention and give play to the role of main channel of classroom teaching. The studies focused on how to deeply tap the ideological and political resources of various courses, integrate moral education into the whole process of classroom teaching, so as to improve the function of ideological and political education of professional courses [3]. The same year, the concept of "ideological and political theories teaching in all courses" was proposed by Shanghai Municipal Party Committee and Municipal Government.

It is a comprehensive education concept which means taking high moral values establishment and people cultivation as the fundamental task of education, deeply exploring the ideological and political theories teaching resources of all kinds 
of courses, making all kinds of courses and ideological and political theory courses go hand in hand to form a synergistic effect, and constructing an education pattern involving all staff, the whole process and the whole curriculum. This concept emphasizes that in addition to knowledge, professional courses also have the function of ideological and political and ideological [4]. Following the National Conference on Ideological and Political Work in Colleges and Universities held in 2016, at which General Secretary Xi Jinping stressed that ideological and political work should be integrated into the whole process of education and teaching to create a new situation in the development of China's higher education, the idea of "ideological and political theories teaching in all courses" has been deeply rooted in people's mind, and has rapidly become a hot topic in academic research and the direction of efforts of various courses in colleges and universities. The development from "ideological and political courses" to "ideological and political theories teaching in all courses" shows that the CPC Central Committee with Xi Jinping as the core attaches great importance to ideological and political education in colleges and universities in the new era, and also indicates the basic trend of innovative development of ideological and political education mode in the future.

\section{CURRENT SITUATION OF IDEOLOGICAL AND POLITICAL THEORIES TEACHING IN COLLEGE ENGLISH CURRICULUM}

It must be acknowledged that College English is a course in which there are frequent collision and blending between Chinese and Western thoughts and cultures. It should be noticed that there is a big change in the Guidelines for College English Teaching issued in 2017, where the idea of being "ideological" is repeatedly referred to. The emphasis on "ideology" actually reflects the necessity and importance of ideological and political education in College English teaching. However, there are some problems in this aspect of College English curriculum for a long time.

First of all, there is a lack of Chinese ideological and cultural content in the teaching materials. In the past, most college English textbooks in China adopted original English articles, emphasizing the learning of the "authentic" language and culture. As a result, some college students may pour out words of Western culture, but they don't have a good knowledge about Chinese excellent traditional culture, or they cannot express it in English. Secondly, the lack of ideological and political education elements in teaching priorities is unquestionable. In the process of teaching practice, English teachers are usually accustomed to drilling students in learning language skills and focus on explaining isolated language points, which should be the carrier of ideas. However, in fact, College English teaching is rarely related to such ideological content that is thought to have noting to do with language teaching. Even if there occasionally appear ideological and political elements in teaching materials, the content is superficial because the connotation is often ignored. Thirdly, the ideological and political education method is rigid and outdated. Most College English teachers lack of thinking and innovation on how to integrate ideological and political education into foreign language teaching. They do not arouse students' reflection on how to cultivate pragmatic understanding and expression ability as well as improve cultural awareness. They also fail to make students deeply understand and realize how to develop "national feelings" and "world vision". Therefore, it is necessary to carry out the ideological and political reform of College English curriculum in a down-to-earth way.

\section{SUGGESTIONS ON IDEOLOGICAL AND PoliticAL REFORM OF COLLEGE ENGLISH TEACHING}

In the new era, high-end professionals who can meet the requirements of the times and social needs should not only have a high level of English, but also have excellent ideological and political quality. So it is necessary for every English teacher to explore the way of transforming College English curriculum and construct a new pattern of "ideological and political theories teaching".

\section{A. Tapping Ideological and Political Education Resources}

In the Guidelines for College English Teaching, the objectives of this course are divided into basic level, improvement level and extension level. Each level has different requirements for listening, speaking, reading, writing and vocabulary. It cannot be denied that in College English teaching, these goals and requirements should first be met. At the same time, the achievement of ideological and political education goal should also be given a serious consideration by improving the ideological nature of the curriculum. It should be clear that the ideological and political ideas mentioned here do not exclusively refer to Marxism, Mao Zedong Thought, Deng Xiaoping Theory and the Three Represents Theory. What is more important and realistic about the ideological and political education is to guide and instruct students to develop correct values, which is just what college English teachers must do.

The correct values include two parts: the core values of socialism and Chinese traditional cultural values. The core values of socialism refer to prosperity, democracy, civilization, harmony, freedom, equality, justice, rule of law, patriotism, dedication, integrity and friendliness. Chinese traditional cultural values can be summarized as responsibility, obligation, community and harmony. The correct guidance of students' values can help them to build up confidence in the path, theory, system and culture of socialism with Chinese characteristics. In this process, the timeliness, effectiveness and ideological nature of College English teaching can be enhanced [5].

The tapping of ideological and political education resources in College English curriculum can be done from the following aspects. The first thing is the in-depth excavation of ideological and political education elements from the main teaching materials that are being used now. The teachers can fully explore these materials and find out the "points" that can help cultivate or enhance students' cultural confidence unconsciously. Secondly, some language learning materials should be supplemented in order to achieve the goal of ideological and political education. The Governance of China, a compilation of Xi Jinping's speeches, talks, interviews, instructions, and correspondence is no doubt the best choice. In the book we can see how $\mathrm{Xi}$ offered his thoughts, views and 
judgments, and answers to a series of important theoretical and practical questions about the Party and the country in these changing times. More importantly it bears the task of international communication because it can enhance the rest of the world's understanding of the Chinese government's philosophy and its domestic and foreign policies. With the most standard way of translation approved by the experts of the Central Bureau of Compilation and Translation, The Governance of China provides a lot of exquisite use of the English, which is worth our study. The comparative learning of some points of the book of both Chinese and English versions will not only enable students to understand China's social system, history and culture, but also enable them to appreciate the diction and sentences, especially some translation skills. As for the other supplementary materials, English versions of Chinese cultural classics, reports and comments from Chinese English media and Western media, etc. can be the resources.

\section{B. Combining the First Classroom Teaching and the Second Classroom Activities}

Successful teaching practice must be based on a scientific and systematic design. In terms of how to determine and use ideological and political education resources, it is necessary for College English teaching team to design a mode, in which the first classroom teaching and research groups should be organized and the second classroom activity instruction channels should be established.

First of all, the team members should sort out and discuss all the ideas, and find out the fusion points between the basic requirements of College English teaching and the language materials of ideological and political education, so that such language materials can be used to train the basic skills of listening, speaking, reading, writing and translation. The key to designing the first classroom teaching is to find out the fit "points" in the main textbooks and to collect, screen and extract the supplementary language materials with the attention to the materials' quantity and quality, so as to maximize their effectiveness for ideological and political education while fulfilling the basic language teaching objectives.

Secondly, we should give full play to the supplementary role of the second classroom activities to stimulate students' higher interest in learning and stronger sense of participation. The College English teaching team can join hands with the student work department to form the second classroom activity instruction team with designated persons responsible for organizing and guiding students to participate in competitions. For example, "FLTRP Cup" English Speaking, Writing and Reading Contests are the opportunities to be made full use of. In preliminaries topics that match the socialist core values and traditional values can be set, thus students can clarify their outlooks on life, the world and values when they devote to preparation, discussion and debate.

In addition, it is suggested that activities of multilingual contests centered on how to "tell China's stories well, make Chinese voice heard" should be held on campus and students from home and abroad are encouraged to attend the competitions, which may form an atmosphere to study Chinese culture.
To sum up, the combination of "the first classroom teaching" and "the second classroom activities" should embody the concepts as follows: training students' practical ability of using language, appropriate application of ideological and political education materials, stimulating students' sense of participation and confidence, guiding students to adhere to the socialist core values.

\section{Integrating Ideological and Political Content into the Whole College English Curriculum System}

In the system of moral education in the whole curriculum, College English should give full play to the educational function and integrate the socialist core values into teaching. On the one hand, in the education and teaching process, the cultural appeal of curriculum can not be ignored and the cultural nature of foreign language teaching should be persisted so as to realize the unity of knowledge impartment and value guidance [6]. On the other hand, College English teaching based on the idea of "ideological and political theories teaching in all Courses" should meet the needs of the whole curriculum system and the needs of students as individuals. Therefore, the construction of curriculum system should be given a careful consideration.

It is advised that the whole course system of College English should be composed of English Compulsory courses and elective courses. The course content includes English for general purpose (EGP), for special purpose (ESP) and for academic purpose (EAP). The teaching methods can be classroom teaching or autonomous learning. The students' individual needs can be roughly divided into the following categories of grasping basic language skills, passing level examinations (CET-4, CET-6, postgraduate entrance examination, IELTS and TOEFL, etc.) and preparing for future careers. The whole curriculum system of College English should be dedicated to creating a characteristic of providing personalized, all-round and tracking service to students and serving the school's objective of training international talent effectively. What's more, from the perspective of English teachers, their academic interests can be met, professional development be achieved and research work be promoted. What should be known and emphasized is ideological and political education is the key factor in the process of the construction of this curriculum system and the implementation of teaching. The lifelong development of students and teachers must be guided by socialist core values.

\section{Improving English Teachers' Ability of Carrying Out Ideological and Political Education}

It is impossible for anyone to keep abreast of the developing situation unless they study harder. First of all, College English teachers should constantly absorb their professional knowledge while learning ideological and political theories, improve their political stance, deeply comprehend the spirit of the 19th CPC National Congress and Xi's thoughts on socialism with Chinese characteristics in the new era. In this way, they can strengthen the socialist core values with greater conviction, build up confidence in the socialist path, theory, system and culture, and cultivate good qualities and temperament. Armed with ideological and political 
theories and professional knowledge, English teachers can surely do well in teaching and educating people by words and deeds, which will exert a gradual, uplifting influence on students' thought, emotion, personality and aesthetic conceptions [7].

Secondly, a plan should be made for English teachers to comprehend and master language materials that can be used to achieve the goal of ideological and political education through self-study and discussion in a fixed time, so as to make the promotion of political and professional quality complement each other. The English version of The Governance of China should be studied carefully and discussed deeply to appreciate its translation skills and methods. A series of teaching research on ideological and political education in the College English course can also be systematically carried out.

Thirdly, colleges and universities should provide support and guarantee for improving teachers' ideological and political education ability. The teacher training department should make arrangements to invite scholars from domestic universities to give lectures, or send teachers to attend academic conferences, etc. Through planned training, teachers will gain more knowledge about teaching and research methods, topic selection and other aspects of curriculum ideological and political education, which helps make more academic achievements on College English ideological and political education.

\section{CONCLUSION}

The idea of "ideological and political theories teaching" is a new subject facing College English course in the new era, and also a historical mission it must shoulder. In today's international environment, where cultural imbalance and cultural hegemony are obvious, College English teaching is to help students truly and thoroughly understand China's current social, political and economic problems, help students tell Chin's stories well in English so that the West can understand China's attitudes and views. College English course in China in the new era should construct the teaching mode of "ideological and political education" and improve the design of level-based teaching to integrate moral education into language teaching.
The transformation of ideological and political theories teaching in College English curriculum can reshape the connotation of the course, so that the English teaching can not only meet the needs of language learning, but also serve the needs of training talents with national emotions and world views.

\section{ACKNOWLEDGMENT}

The study is supported by The Research Center for Foreign Language Education in Engineering Institutes of Jilin Province, The Key Research Base of Humanities and Social Science of Jilin Province.

\section{REFERENCES}

[1] Xi Jinping, "Secure a Decisive Victory in Building a Moderately Prosperous Society in All Respects and Strive for the Great Success of Socialism with Chinese Characteristics for a New Era"_-Delivered at the 19th National Congress of the Communist Party of China. From: http://language.chinadaily.com.cn/19thcpcnationalcongress/201711/06/content_34188086.htm

[2] Xi Jinping, The Speech Delivered at a Grand Gathering in Beijing Marking the 95th Anniversary of the Founding of the CPC. From: http://www.china.com.cn/cppcc/2016-07/02/content_38796697.htm

[3] Du Gangyue and Sun Ruijuan, "Methodology research of ideologica and political theories teaching in College English course" (in Chinese), J. Journal of Yan'an University (Social Science Edition), vol. 41, pp. 122 126, August 2019.

[4] An Xiumei, "A study on the function of ideological and political theories teaching in College English" (in Chinese), J. Comparative Study of Cultural Innovation, vol. 2, pp. 84-85, April 2018.

[5] Mei Qiang, "Exploration and practice of ideological and politica theories teaching in two kinds of full coverage courses in colleges and universities" (in Chinese), J. China University Teaching, pp. 20-29+5, September 2018.

[6] Gao Deyi and Zong Aidong, "Ideological and political theories teaching in all courses: the main channel of classroom education" (in Chinese), J. Leading Journal of Ideological \& Theoretical Education, pp. 31-34, January 2017

[7] Huang Yifan, "College English teaching under the curriculum system of ideological and political theories teaching" (in Chinese), J. Cultural and Educational Information, pp. 209-211, February 2018. 